\title{
IMPLEMENTASI ASAS KESETARAAN DALAM AKAD PEMBIAYAAN MURABAHAH PADA KPR-BTN IB DI BTN SYARIAH CABANG BANJARMASIN
}

\author{
Fajrul Ilmi \\ Universitas Islam Negeri Antasari Banjarmasin \\ e-mail: Arue1006@gmail.com
}

\begin{abstract}
ABSTRAK
Secara umum dalam membuat suatu kontrak berisi aturan-aturan yang mengakomodasi kepentingan para pihak, baik pihak produsen maupun konsumen. Akan tetapi produsen sebagai pihak yang menyusun kontrak seringkali lebih memperhatikan kepentingannya. Sehingga, konsumen yang seharusnya berada dalam posisi tawar yang lebih baik dibandingkan pihak produsen menjadi pihak yang lemah.Unsur kesetaraan sebagai salah satu asas dalam akad di Bank Syariah menunjukkan tidak ada hubungan salah satu pihak berada dalam posisi yang lebih unggul dibanding pihak yang lain sehingga seolah bisa memaksakan suatu ketentuan yang menguntungkan. Standar kontrak dengan pencantuman klausula eksonerasi, tidak boleh terjadi di Bank Syariah ketika asas kesetaraan diimplementasikan.Berdasarkan hal tersebut, maka penerapan asas kesetaraan berfungsi untuk menjamin kesamaan kedudukan para pihak, yaitu saat sebelum terjadinya akad atau proses penyusunan akad, para pihak mempunyai posisi tawar yang sama, dalam penentuan isi akad, para pihak.
\end{abstract}

Kata Kunci: Asas Kesetaraan, Akad Pembiayaan Murabahah, KPR-BTN IB.

\section{PENDAHULUAN}

Islam merupakan way of life yang mengatur segala aspek kehidupan manusia termasuk aspek ekonomi. Ekonomi dalam islam dibangun untuk tujuan suci berdasarkan ajaran Islam (al-Quran) dan dicapai dengan caracara yang sesuai ajaran Islam pula.

Dunia bisnis merupakan dunia yang paling ramai dibicarakan publik. Ramainya pembicaraan masalah ini karena kemajuan suatu Negara di ukur dari perkembangan ekonominya. Berkembangnya lembaga keuangan perbankan yang berlandaskan syariah Islam di negara-negara muslim maupun pluraris sedikit banyaknya membawa pengaruh terhadap Indonesia yang merupakan negara yang mayoritas pendudukanya beragama Islam walaupun bukan negara muslim. Indonesia yang jumlah umat Islamnya terbesar dibandingkan dengan negara-negara muslim, tentunya kebutuhan akan lembaga keuangan yang berlandaskan prinsip syariah sangat banyak.

Menjawab kebutuhan masyarakat Bank Syariah bukan sekedar lembaga keuangan yang bersifat sosial, namun bank syariah juga sebaga 
lembaga bisnis dalam rangka memperbaiki perekonomian masayarakat yang juga sekaligus meningkatkan harkat dan martabat hidup umat Islam khususnya. Lembaga perbankan yang menganut sistem syariah tidak serta merta hanya berorientasi untuk meraup dana Islam sebanyak-banyaknya tanpa memberi manfaat, kontribusi dan implikasi positif kepada usaha peningkatan kesejahteraan umat secara menyeluruh, utamanya dalam pengembangan usaha kecil dan menengah yang mayoritas dimiliki umat Islam.

Setiap kegiatan atau proses transaksi yang dilakukan pada perbankan syariah, disamping memperhatikan hal-hal yang diatur dalam hukum positif, juga berjalanmengikutiaturan hukum Islam. Oleh karena itu, transaksi tersebut tidak akan terlepas dari proses transaksi dalam fikih muamalah.

PBI No.9/19/PBI/2007 menjelaskan tentang pelaksanaan prinsip syariah dalam kegiatan penghimpunan dana dan penyaluran dana serta pelayanan jasa bagi bank syariah sebagaimana telah diubah dengan PBI No.10/16/PBI/2008 tentang perubahan terhadap PBI No.9/19/PBI/2007, menyebutkan bahwa untuk mengantisipasi timbulnya resiko reputasi atas pesatnya perkembangan inovasi transaksi keuangan syariah tersebut, diperlukan kesesuaian dengan prinsip syariah secara istiqomah sebagaimana difatwakan oleh Dewan Syariah Nasional. Sedangkan fatwa sendiri merupakan hasil Ijtihad yang dilakukan oleh para ulama.

Penjelasan di atas menegaskan bahwa falsafah dasar perbankan syariah mengacu kepada ajaran agama islam yang bersumber pada AlQur'an, hadits, dan ijtihad ulama. Ajaran agama Islam mengajarkan kepada umatnya untuk berusaha mendapatkan kehidupan yang baik di dunia sekaligus memperoleh kehidupan yang baik di akhirat. Islam tidak mengizinkan pemenuhan kebutuhan hidup dengan menghalalkan segala cara, melainkan mengatur bagaimana seharusnya manusia melakukan pola konsumsi, simpanan, dan investasi sesuai dengan ajaran Islam.

Pembiayaan murabahah merupakan salah satu solusi untuk meningkatkan perekonomian rakyat yang dapat diberikan kepada masyarakat oleh bank yang kegiatan usahanya berdasarkan prinsip syariah. Secara sederhana, murabahah berarti suatu penjualan barang seharga barang tersebut ditambah keuntungan yang disepakati. Seseorang membeli barang kemudian misalnya menjualnya kembali dengan keuntungan tertentu. Berapa besar keuntungan tersebut dapat dinyatakan dalam nominal rupiah tertentu atau dalam bentuk persentase dari harga pembeliannya. (Karim, 2007).

Murabahah dalam teknis perbankan adalah jual beli antara bank selaku penyedia barang dengan nasabah yang memesan untuk membeli barang, bank memperoleh keuntungan jual beli yang disepakati bersama. (Badrulzaman, 2001). Harga jual bank adalah harga beli dari suplier ditambah keuntungan yang disepakati bersama.

Dengan demikian, nasabah pembeli mengetahui berapa harga dari barang yang diinginkan dan berapa keuntungan yang diperoleh pihak bank. Nasabah pembeli akan merasa tentram karena ada keterbukaan dari pihak 
bank dalam pelaksanaan transaksi murabahah dan tidak khawatir akan banyaknya keuntungan yang diperoleh pihak bank.

Kegiatan usaha bank syariah murabahah merupakan usaha yang terbanyak dijalankan, tidak hanya di indonesia tetapi juga di negara-negara lain yang melakukan kegiatan perbankan dengan sistem bagi hasil.

Islamic Development Bank (IDB) kegiatan usahanya masih terfokus pada skim murabahah yang cendrung merupakan pembiayaan jangka pendek dan memiliki dampak positif terhadap perekonomian yang lebih kecil dibandingkan dengan skim mudharabah. (Muhammad, 2002).

Dominasi penggunaan akad murabahah dalam pembiayaan tidak terlepas dari berbagai faktor, antara lain karakteristik pembiayaan murabahah yang returnya dapat diperkirakan serta relatif lebih mudah dan dapat memenuhi berbagai macam permintaan nasabah. Selain itu pembiayaan murabahah mudah dipahami dan dijalankan oleh masyarakat dan pihak bank.

Pembiayaan yang diberikan oleh bank syariah harus dituangkan dalam bentuk perjanjian tertulis. Hal ini sebagaimana ditegaskan dalam UndangUndang Perbankan pada pasal 8 ayat 2 dan penjelasannya yang dirumuskan sebagai berikut: Bank Umum berdasarkan Prinsip Syariah, sesuai dengan ketentuan yang ditetapkan oleh Bank Indonesia, dan penjelasnnya, yang dirumuskan sebagai berikut: "pokok-pokok ketentuan yang ditetapkan oleh Bank Indonesia memuat antara lain: "pemberian kredit atau pembiayaan berdasarkan prinsip syariah dibuat dalam bentuk perjanjian tertulis...".

Dalam prakteknya perbankan mengacu pada penjelasan pasal 8 ayat 2 UUP, karena terkait fungsinya sebagai alat bukti bagi para pihak yang membuatnya. Sebagaimana juga disebutkan dalam pasal 1 ayat 13 UndangUndang Perbankan Syariah "akad adalah kesepakatan tertulis antara bank syariah atau unit usaha syariah dan pihak lain yang memuat adanya hak dan kewajiban bagi masing-masing pihak sesuai dengan prinsip syariah".

Akad sebagai cerminan telah terjadinya hubungan kesepakatan antara para pihak harus mencerminkan asas-asas akad yang tertuang dalam perundang-undangan dan hukum muamalah Islam. Berawal dari akad inilah yang membedakan Bank Syariah dengan Bank Konvensional, karena akad yang ditetapkan di perbankan syariah dan lembaga keuangan syariah non bank lainnya, memiliki konsekuensi duniawi dan ukhrawi karena dilakukan berdasarkan hukum Islam. Dalam penerapan pola hubungan akad ini sudah seharusnya tidak terdapat penyimpangan-penyimpangan dari kesepakatan yang telah dibuat oleh para pihak karena masing-masing menyadari akan pertanggungjawaban dari akad tersebut. (Yulianti, 2008).

Dalam hukum muamalah Islam terdapat asas-asas akad yang melandasi penegakan atau pelaksanaan akad. Asas-asas tersebut adalah asas sukarela, amanah, kehati-hatian, tidak berubah, saling menguntungkan, taswiyah (kesetaraan), transparansi, kemampuan, kemudahan, itikad baik, dan sebab yang halal. Salah satu asas tersebut adalah asas taswiyah atau kesetaraan. Kompilasi Hukum Ekonomi Syariah menyebutkan bahwa akad harus dilakukan berdasarkan taswiyah atau 
kesetaraan yaitu para pihak dalam setiap akad memiliki kedudukan yang setara dan mempunyai hak dan kewajiban yang seimbang. (Siregar, 2020).

Hukum Perdata Islam juga telah menetapkan beberapa asas kontrak yang berpengaruh kepada pelaksanaan kontrak yang dilaksanakan oleh para pihak yang berkepentingan. Jika asas-asas ini tidak terpenuhi dalam melaksanakan kontrak, maka akan berakibat batal atau tidak sahnya kontrak yang dibuatnya. (Rahman, 2007).

Asas taswiyah memberikan dasar bahwa dalam melakukan suatu perjanjian para pihak mempunyai kedudukan yang sama, sehingga dalam menentukan segala sesuatunya mengenai isi perjanjian, para pihak tidak ada yang merasa lebih tinggi kedudukannya. Landasan asas ini terdapat dalam al-qur'an yang artinya:

Hai manusia,Sesungguhnya Kami menciptakan kamu dari seorang lakilaki dan seorang perempuan dan menjadikan kamu berbangsa - bangsa dan bersuku-suku supaya kamu saling kenal-mengenal. Sesungguhnya orang yang paling mulia diantara kamu disisi Allah ialah orang yang paling taqwa diantara kamu. Sesungguhnya Allah Maha mengetahui lagi Maha Mengenal”.(Q.S al-Hujurat:13).

Secara umum dalam membuat suatu kontrak berisiaturan-aturanyang mengakomodasi kepentingan para pihak, baik pihak produsen maupun konsumen. Akan tetapi produsen sebagai pihak yang menyusun kontrak seringkali lebih memperhatikan kepentingannya. Sehingga, konsumen yang seharusnya berada dalam posisi tawar yang lebih baik dibandingkan pihak produsen menjadi pihak yang lemah.

Unsur kesetaraan sebagai salah satu asas dalam akad di Bank Syariah menunjukkan tidak ada hubungan salah satu pihak berada dalam posisi yang lebih unggul dibanding pihak yang lain sehingga seolah bisa memaksakan suatu ketentuan yang menguntungkan. Standar kontrak dengan pencantuman klausula eksonerasi, tidak boleh terjadi di Bank Syariah ketika asas kesetaraan diimplementasikan. Dengan dikeluarkan Undang-undang No. 10 tahun 1998 dapat disimpulkan bahwa sistem perbankan syariah dikembangkan dengan tujuan membuka peluang pembiayaan bagi pengembangan usaha berdasarkan prinsip kemitraan. Dalam prinsip ini, konsep yang diterapkan adalah hubungan antar investor yang harmonis. (Wirdyaningsih, 2005).

Berdasarkan hal tersebut, maka penerapan asas kesetaraan berfungsi untuk menjamin kesamaan kedudukan para pihak, yaitu saat sebelum terjadinya akad atau proses penyusunan akad, para pihak mempunyai posisi tawar yang sama, dalam penentuan isi akad, para pihak mempunyai hak dan kewajiban yang setara seperti yang disebutkan dalam peraturan perundang-undang dan fatwa Dewan Syariah Nasional, serta kedudukan yang seimbang dalam proses penyelesaian apabila terjadi sengketa.

Prinsip kesetaraan kedudukan, yaitu kesetaraan para pihak dalam penyusunan akad, kesetaraan dalam isi akad terkait hak dan kewajiban para pihak, kesetaraan dalam pembagian bagi hasil antara bank dan nasabah, dan kesetaraan dalam penyelesaian sengketa. 


\section{METODE PENELITIAN}

Penelitian ini merupakan jenis penelitian kualitatif kepustakaan.Sumber datanya merupakan data sekunder yang berasal dari sumber kepustakaan seperti buku, jurnal, dan artikel.Motode analisisnya menggunakan analisis deskriptif.

\section{PEMBAHASAN}

\section{A. Asas Kesetaraan (Taswiyah)}

Asas berasal dari bahasa arab asasun yang berarti dasar, basis dan fondasi. Secara terminologi asas adalah dasar atau sesuatu yang menjadi tumpuan berfikir atau berpendapat. (Alwi Hasan, dkk, 2005). Mohammad Daud Ali mengartikan asas apabila dihubungkan dengan kata hukum adalah kebenaran ang dipergunakan sebagai tumpuan berfikir dan alasan berpendapat terutama dalam penegakan dan pelaksanaan hukum. (Ali, 1990).

Kompilasi hukum ekonomi syariah menjelaskan bahwa asas kesetaraan (Taswiyah) adalah para pihak dalam setiap akad memiliki kedudukan yang setara, dan mempunyai hak dan kewajiban yang seimbang. Agus menyebutkan prinsip kesetaraan mengandung pengertian bahwa para pihak mempunyai kedudukan (bargaining position) yang sama sehingga dalam menentukan term and condition dari suatu akad/perjanjian, setiap pihak mempunyai kedudukan yang seimbang.

Mariam menyebutkan dalam bukunya juga menjelaskan bahwa asas Taswiyah (persamaan) memberikan landasan bahwa kedua belah pihak yang melakukan perjanjian mempunyai kedudukan yang sama antara satu dengan yang lainnya. Sehingga, pada saat menentukan hak dan kewajiban masing-masing didasarkan pada asas persamaan. (Badrulzaman, 2001).

Menurut Sri Gambir Hatta, asas Keseimbangan dipahami sebagai keseimbangan kedudukan posisi tawar para pihak dalam menentukan hak dan kewajibannya dalam perjanjian. Ketidak seimbangan posisi menimbulkan ketidakadilan, sehingga perlu intervensi pemerintah untuk melindungi pihak yang lemah melalui penyeragaman syarat-syarat perjanjian. (Hatta, 1999). Sedangkan menurut Ahmadi Miru bahwa keseimbangan antara konsumen dengan produsen dapat dicapai dengan meningkatkan perlindungan terhadap konsumen karena posisi produsen lebih kuat dibandingkan dengan konsumen. (Miru, 2011). 


\section{B. Pembiayaan Murabahah}

\section{Pengertian Murabahah}

Murabahah Berasal dari kata ribhu (الربح) berarti keuntungan, laba, faidah. (Munawwir, 1984). Murabahah adalah jual beli barang dengan tambahan harga dari harga pembelian pertama secara jujur. (Mujieb, 1994). Sedangkan Hasbi As Shiddiqi mendefinisikan murabahah tersebut dengan penjualan barang disertai keuntungan (laba) tertentu. Pendapat lain mengatakan bahwa murabahah mirip seperti jual beli, namun harga dan keuntungan disepakati secara bersama oleh penjual dan pembeli. Secara istilah, murabahah adalah akad jual beli barang dengan menyatakan harga perolehan dan keuntungan (margin) yang disepakati oleh penjual dan pembeli. (Karim, 2007). Dalam istilah perbankan syariah maknanya akad jual beli atas barang tertentu dimana penjual menyebutkan harga pembelian barang kepada pembeli kemudian mensyaratkan atasnya keuntungan dalam jumlah tertentu. Sistem pembayarannya berdasakan tempo waktu bayar. (Hardini \& Giharto, 2007).

Murabahah adalah istilah dalam fikih Islam yang berarti suatu bentuk jual beli tertentu ketika penjual menyatakan biaya perolehan barang meliputi harga barang dan biaya-biaya lain yang dikeluarkan untuk memperoleh barang tersebut, dan tingkat keuntungan (margin) yang diinginkan. (Ascarya, 2007).

Perma nomor 2 Tahun 2008 tentang akad menyebutkan bahwa murabahah adalah pembiayaan saling menguntungkan yang dilakukan oleh sahibul al-mal dengan pihak yang membutuhkan melalui transaksi jual beli dengan penjelasan bahwa harga pengadaan barang dan harga jual terdapat nilai lebih yang merupakan keuntungan atau laba bagi sahibul al-mal dan pengembaliannya dilakukan secara tunai atau angsur. (Mughits, 2008).

Undang-undang Nomor 21 Tahun 2008 tentang perbankan syariah memberikan definisi tentang murabahah dalam penjelasan pasal 19 ayat 1 huruf d yang dimaksud akad murabahahadalah akad pembiayaan suatu barang dengan menegaskan harga belinya kepada pembeli dan pembeli membayarnya dengan harga yang lebih sebagai keuntugan yang disepakati.

Menurut Syafii Antonio jual beli murabahah adalah jual beli barang pada harga asal dengan tambahan keuntungan yang disepakati. Dalam jual beli murabahah penjual harus memberitahu harga produk yang ia beli dan menentukan suatu tingkat keuntungan sebagai tambahannya. (Antonio, 1999).

Pembiayaan murabahah adalah pembiayaan dengan sistem jual beli, dimana bank membiayai pembelian barang yang dibutuhkan nasabah. Harga jual kepada nasabah adalah sebesar harga pokok barang ditambah marjin keuntungan yang disepakati antara bank dan nasabah.

Murabahah pada awalnya merupakan konsep jual beli yang sama sekali tidak ada hubungannya dengan pembiayaan. Namun demikian, bentuk jual beli ini kemudian digunakan oleh perbankan syariah dengan menambah beberapa konsep lain sehingga menjadi bentuk pembiayaan. Akan tetapi, validitas transaksi seperti ini tergantung pada beberapa syarat 
yang benar-benar harus diperhatikan agar transaksi tersebut diterima secara syariah. Dalam pembiayaan ini, baik pemilik dana membelikan barang sesuai dengan spesifikasi yang diinginkan oleh nasabah yang membutuhkan pembiayaan, kemudian menjual kepada nasabah tersebut dengan penambahan keuntungan tetap. Sementara nasabah akan mengembalikan utangnya dikemudian hari secara tunai maupun cicil. (Ascarya, 2007).

Selain dalam Undang-undang Nomor10 Tahun1998 tentang perubahan atas Undang-undang Nomor 7 Tahun 1992 tentang perbankan, pengertian murabahah juga dijelaskan dalam fatwa Dewan Syariah Nasional Nomor 04/DSN-MUI/I/2000 tentang murabahah, yaitu menjual suatu barang dengan menegaskan harga belinya kepada pembeli dan pembeli membayarnya dengan harga yang lebih sebagai laba/keuntungan. (Arwani, 2016). Sedangkan dalam PSAK 59 tentang akuntansi Perbankan Syariah paragraph 52 dijelaskan bahwa murabahah adalah akad jual beli barang dengan menyatakan harga perolehan dan keuntungan yang disepakati oleh penjual dan pembeli. (Wiroso, 2005).

\section{Dasar Hukum Murabahah}

Jual beli secara umum termasuk murabahah didalamnya merupakan saran tolong menolong antara sesama manusia, berdasarkan surah an-Nisa ayat 29:

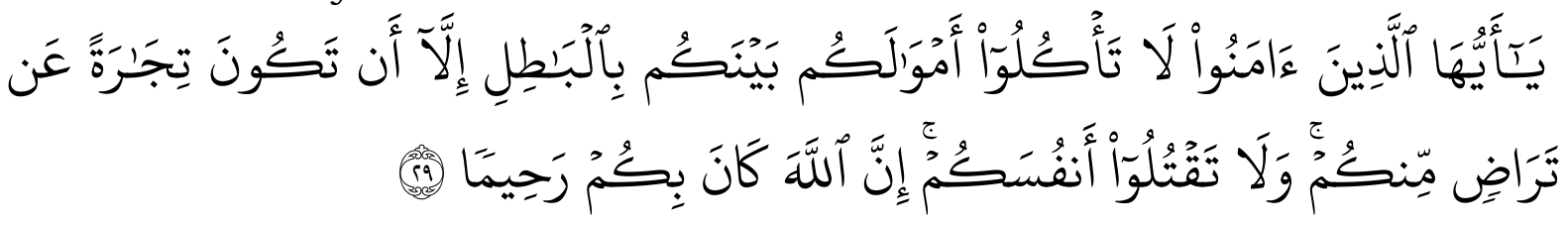

Artinya:

Hai orang-orang yang beriman, janganlah kamu saling memakan harta sesamamu dengan jalan yang batil, kecuali dengan jalan perniagaan yang berlaku dengan suka sama-suka di antara kamu. Dan janganlah kamu membunuh dirimu; sesungguhnya Allah adalah Maha Penyayang kepadamu.

Kemudian dinyatakan pula dalam surah al-Baqarah ayat 275 yang berbunyi:

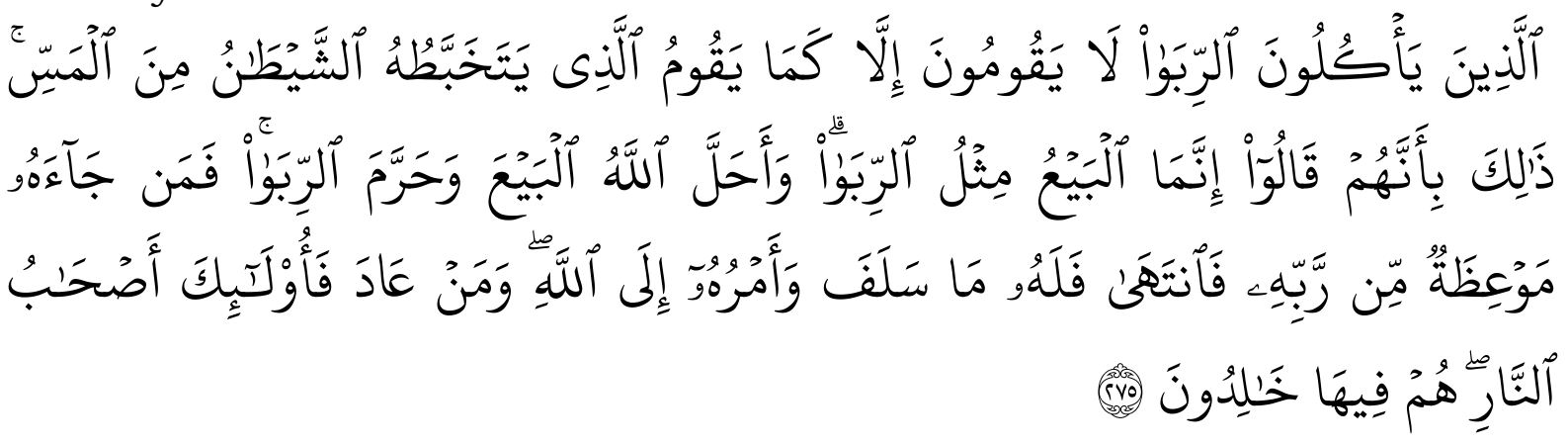


Artinya:

Orang-orang yang makan (mengambil) riba tidak dapat berdiri melainkan seperti berdirinya orang yang kemasukan syaitan lantaran (tekanan) penyakit gila. Keadaan mereka yang demikian itu, adalah disebabkan mereka berkata (berpendapat), sesungguhnya jual beli itu sama dengan riba, padahal Allah telah menghalalkan jual beli dan mengharamkan riba. Orang-orang yang telah sampai kepadanya larangan dari Tuhannya, lalu terus berhenti (dari mengambil riba), maka baginya apa yang telah diambilnya dahulu (sebelum datang larangan); dan urusannya (terserah) kepada Allah. Orang yang kembali (mengambil riba), maka orang itu adalah penghuni-penghuni neraka; mereka kekal di dalamnya.

Murabahah tidak secara spesifik disinggung dalam al-Qur'an dan Hadis, karena, pada dasarnya murabahah belum dikenal pada masa Rasulullah SAW. Hanya saja pada ulama generasi awal seperti Imam Malik dan Syafi'I secara spesifik mengatakan bahwa murabahah adalah halal tanpa memperkuat pendapat mereka dengan hadis khusus tentang hal tersebut. (Saeed, 2004).

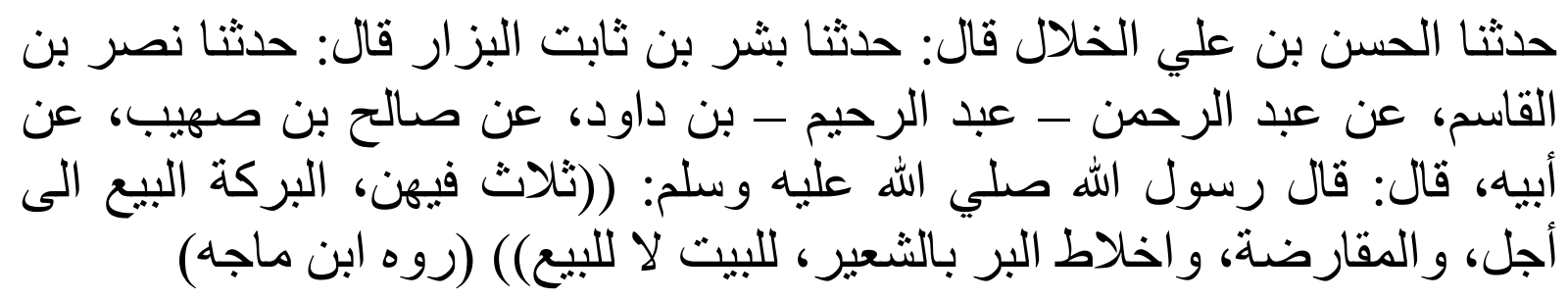

Artinya:

Tiga hal yang didalam nyater dapat keberkahan, pertama menjual dengan tempo pembayaran (murabahah), kedua muqaradhah (nama lain dari mudharabah) dan ketiga mencampur tepung dengan gandum untuk kepentingan rumah bukan untuk diperjualbelikan.

\section{Rukun dan Syarat Murabahah}

Dalam kegiatan jual beli murabahah ada rukun dan syarat yang harus dipenuhi, rukun dari akad murabahah ada beberapa, yaitu: Penjual (ba' $)$, Pembeli (Musytariy), Barang (mabi) dan Shighat dalam bentuk ijab dan qabul.

Sedangkan syarat-syarat murabahah adalah sebagai berikut : a) Pembeli hendaklah betul-betul mengetahui modal sebenarnya dari suatu barang yang hendak dibeli; b) Penjual dan pembeli hendaklah setuju dengan kadar untung atau tambahan harga yang ditetapkan tanpa ada sedikitpun paksaan; c) Barang yang dijual belikan bukanlah barang ribawi; d) Sekiranya barang tersebut telah dibeli dari pihak lain, jual beli yang pertama itu mestilah sah menurut pandangan Islam. (Dewi, 2008).

Beberapa syarat pokok murabahah menurut Usmani, antara lain sebagai berikut : 
a. Murabahah merupakan salah satu bentuk jual beli ketika penjual secara eksplisit menyatakan bahwa biaya perolehan barang yang akan dijualnya dan menjual kepada orang lain dengan menambahkan tingkat keuntungan yang diinginkan.

b. Tingkat keuntungan murabahah dapat ditentukan berdasarkan kesepakatan bersama dalam bentuk lumpsum atau persentase tertentu dari biaya.

c. Semua biaya yang dikeluarkan penjual dalam rangka memperoleh barang dimasukkan ke dalam biaya perolehan untuk menentukan harga agregat

d. Murabahah dikatakan sah hanya ketika biaya-biaya perolehan barang dapat ditentukan dengan pasti.

\section{Manfaat Murabahah}

Sesuai dengan sifat bisnis (tijarah), transaksi murabahah memiliki beberapa manfaat, demikian juga resiko yang harus diantisipasi. Murabahah memberi banyak manfaat kepada bank syariahal salah satunya adalah adanya keuntungan yang muncul dari selisiih harga beli dari penjual dengan harga jual kepada nasabahal Selain itu, sistem murabahah juga sangat sederhana.

Adapun kemungkinan resiko yang harus diantisipasi antara lain sebagai berikut:

a. Default atau kelalaian; nasabah sengaja tidak membayar angsuran.

b. Fluktuasi harga komparatif. Ini terjadi bila harga suatu barang di pasar naik setelah bank membelikannya untuk nasabah.

c. Penolakan nasabah; barang yang dikirim bisa saja ditolak oleh nasabah karena berbagai sebab. Karena itu sebaiknya dilindungi dengan asuransi. Kemungkinan lain karena nasabah merasa spesifikasi barang tersebut berbeda dengan yang ia pesan.

d. Dijual; karena murabahah bersifat jual beli dengan utang, maka ketika kontrak ditandatangani, barang itu milik nasabah. Nasabah bebas melakukan apapun terhadap aset miliknya tersebut, termasuk untuk menjualnya. Jika terjadi demikan, resiko untuk default akan besar. (Antonio, 1999).

\section{Implementasi asas kesetaraan}

Asas Taswiyah dalam akad atau perjanjian dapat diartikan sebagai persamaan atau kesetaraan, dalam hukum kontrak menggunakan istilah keseimbangan. Asas ini merupakan pelaksanaan dari prinsip itikad baik, prinsip transaksi yang dilandasi oleh kejujuran dalam menentukan sesuatu hal, termasuk di dalamnya dalam hal menentukan "margin keuntungan" karena nantinya akan berakibat dalam penentuan margin pada dasarnya ada perbedaan dalam angsuran antara 2 (dua) tahun dengan angsuran dengan jangka waktu lebih dari 2 (dua) tahun (yang terjadi adalah pembayaran angsuran lebih besar dari pada yang seharusnya).

Meskipun secara factual jarang terjadi keseimbangan antara pihak dalam bertransaksi, namun hokum perjanjian islam tetap menekankan 
perlu keseimbangan itu. Baik keseimbangan antara apa yang diberikan dan apa yang diterima maupun keseimbangan dalam memikul resiko.

Asas keseimbangan dalam bertransaksi tercermin pada dibatalkannya suatua kad yang mengalami ketidakseimbangan prestasi yang mencolok. Asas keseimbangan dalam memikul resiko tercermin dalam larangan terhadap transaksi riba, dimana dalam konse pribahasa debitur yang memikul segala resiko atas kerugiaan usaha, sementara kreditor bebas sama sekali dan harus mendapatkan prosentase tertentu sekalipun dananya mengelami pengembalian yang negatif. (Yasardin, 2018).

Asas keseimbangan (Taswiyah)dalam hukum perjanjian Islam memandang perlu adanya keseimbangan antara orang yang berakad, baik keseimbangan antara apa yang diberikannya dan apa yang diterima maupun keseimbangan dalam menanggung resiko. (Yasardin, 2018). Artinya, bahwa seseorang yang melakukan transaksi harus menghindari adanya unsur riba dan merugikan salah satu pihak. Dengan demikian, larangan riba merupakan prinsip yang sangat penting dan mendasar. Selain itu, juga harus menghindari terjadinya mudharat pada salah satu/ kedua belah pihak. Karena setiap muamalah yang menimbulkan mudharat adalah batal, sebagaimana hadis Rasulullah Saw. yang dikutip oleh Imam Nakha'i dan M. Asra Maksum dari kitab al-Muwatta' Imam Malik yang berbunyi: (Nakha’i \& Ma'sum, 2011)

$$
\text { أن رسول الله }
$$

Mengacu pada dalil di atas maka perlu keseimbangan dalam melakukan perjanjian (contract) perlu diperhatikan dengan baik sehingga tidak menimbulkan prasangka maupun perselisihan di kemudian hari.

Berdasarkan uraian diatas maka penulis dapat menyimpulkan bahwa asas kesetaraan (musawwa) menurut perjanjian islam yaitu keseimbangan posisi antara para pihak yang mana hak dan kewajiban masing-masing pihak terakomodasi dalam isi kontrak sebagaimana mestinya tanpa memihak pada salah satu pihak yang melakukan kontrak.

\section{Penerapan Asas Kesetaraan Dalam Akad Pembiayaan Murabahah Pada KPR-BTN IB di BTN Syariah Cabang Banjarmasin}

Aplikasi akad dalam perbankan syariah adalah suatu bentuk perjanjian/akad yang telah dibakukan isinya (boilerplate) atau Standar kontrak. Hal ini sering menyebabkan perjanjian tersebut menjadi memenuhi kepentingan dan melindungi bagi salah satu pihak saja, sedangkan bagi pihak yang lain akan diberatkan.

Sebenarnya ketentuan dalam pembuatan perjanjian baku ini dilakukan oleh pihak perbankan syariah dikarenakan untuk efektivitas karena untuk memenuhi permintaan pembiayaan terutama dalam produk Murabahah yang tinggi dari masyarakat. Namun tentunya hal ini tidak boleh mengidahkan dari ketentuan mengenai kesepakatan yang harus seimbang dari kedua belah pihak.

Secara jelas peraturan ini tercantum dalam Undang-undang Nomor 8 Tahun 1999 tentang perlindungan konsumen, yang secara khusus dalam 
Pasal 18 mengatur tentang klasula baku yang diperbolehkan dengan syarat-syarat yang tidak boleh dilanggar oleh pihak produsen dalam hal ini pihak Bank sebagai Penjual. Untuk melihat bentuk penerapan dari asas keseimbangan atau kesetaraan yang dalam asas perjanjian sesuai Islam disebut dengan Al-Musawa, maka diperlukan bentuk analisis terhadap kelompok klausul yang di dalamnya terdapat hak dan kewajiban dari kedua belah pihak dalam Akad Pembiayaan Murabahah.

\section{Analsis Penerapan Asas Kesetaraan Pada Pembiayaan Murabahah di Bank BTN Syariah Cabang Banjarmasin}

\section{Analisis Penerapan Asas Kesetaraan dalam Klausul Tentang Jumlah Pembiayaan, Tujuan Pembiayaan, Bentuk Pembiayaan, Batas Waktu, Pembayaran Ekstra/ Pelunasan Dipercepat ${ }^{1}$}

Tujuan pembiayaan murabahah adalah memberikan pembiayaan dengan dasar jual beli barang dengan harga jual ditambah marjin keuntungan yang disepakati bersama dengan pembayaran ditangguhkan (angsuran) dalam jangka waktu yang telah disepakati.

Pada akad pembiayaan murabahah KPR-BTN IB tidak dicantumkan Tujuan pembiayaan yang seharusnya disampaikan secara detail. Hal ini dapat menjamin kedua belah pihak mendapatkan perlindungan hukum lebih baik.

Jumlah pembiayaan juga harus disebutkan secara jelas. Pihak bank telah menyebutkan secara jelas berapa harga pokok, marjin keuntungan dan jangka waktu pembayaran.

Hanya saja yang menjadi permasalahan prosedur sebelum akad dibuat terkait dengan hak bank dalam menentukan marjin keuntungan dan kewajiban untuk memberikan nasabah kesempatan negosiasi terhadap kesepakatan marjin keuntungan dan jangka waktu pembayaran. Padahal nasabah mempunyai hak terhadap hal tesebut sesuai dengan asas Taswiyah tercantum jelas bahwa kedua belah pihak yang mengikatkan diri dalam akad pembiayaan mempunyai hak dan kewajiban yang sama dalam menentukan bargaining position dan terms and condition dalam klausul yang dibuat.

Berdasarkan uraian diatas penulis menyimpulkan bahwa bank belum dapat menerapkan secara sempurna asas kesetaraan. Seharusnya pihak bank dalam menentukan marjin keuntungan dan jangka waktu pembayaran dikomunikasikan dengan nasabah tentang acuan dalam penentuan tersebut agar terciptanya kesetaraan antara para pihak. Dengan pertimbangan ekonomi dan kemampuan nasabah sehingga nasabah dapat dengan lega/ ridha menerimanya.

\section{Analisis Penerapan Asas Kesetaraan dalam Klausul Tentang Barang Agunan (Jaminan)}

${ }^{1}$ Disimpulkan dari akad Pembiayaan Murabahah KPR-BTN iB, BTN Syariah Cabang Banjarmasin 
Jaminan atau yang lebih dikenal dengan rahn dalam islam merupakan perjanjian penyerahan barang untuk menjadi agunan dari fasilitas pembiayaan yang diberikan. Dalam praktek murabahah karena nasabah tidak membayar barang secara tunai, maka bank akan meminta jaminan untuk menjamin dibayarnya angsuran sesuai dengan ketentuan.

Disini terlihat jelas adanya keseimbangan antara kedua belah pihak yang melakukan perjanjian, karena hak bank untuk meminta jaminan atas keseriusan nasabah melakukan pembayaran dan kewajiban nasabah untuk menyerahkannya sebagai bukti keseriusannya demi tercipta perlindungan hukum bagi keduanya.

Tetapi dalam prakteknya jaminan merupakan suatu keharusan. Tanpa adanya jaminan maka pembiayaan tidak akan dikabulkan dan besarnya harus mencover nilai modal yang dikeluarkan oleh bank beserta resiko kerugian yang mungkin terjadi. Padahal kedudukan jaminan bukan untuk mencover kerugian serta bukan syarat wajib dalam suatu pembiayaan.

Penulis melihat bahwa adanya kesetaraan kedua belah pihak. Yang mana hak bank untuk mendapat kepastian pengembalian pembiayaan dan hak bank mendapat pembiayaan. Begitu juga kewajiban nasabah untuk membayar sesua dengan kesepakatan dan kewajiban bank untuk memberikan pembiayaan.

\section{Analisis Penerapan Asas Kesetaraan dalam Klausul Tentang Uang Muka (Urbun)}

Ketentuan tentang uang muka ini sebenarnya diperbolehkan tetapi bukan merupakan keharusan untuk dilakukan nasabah, hal ini digunakan sebagai penilaian oleh pihak bank atas kesungguhan nasabah mengajukan pembiayaan.

Uang muka diperbolehkan asal dengan kesepakatan kedua belah pihak. Kedua belah pihak mempunyai kedudukan yang seimbang dalam hak dan kewajiban dalam menentukan nominal uang muka, namun dalam prakteknya uang muka merupakan kewajiban nasabah dan hak bank untuk meminta uang muka dengan nominal yang sudah ditentukan. Karena uang muka merupakan salah satu alat untuk mengukur kelayakan nasabah dalam mengajukan pembiayaan sebagai gambaran kondisi keuangan nasabah.

Menurut penulis, sah-sah saja pihak bank menentukan uang muka dalam artinya untuk membuktikan bahwa ekonomi nasabah dalam kategori mampu mendapatkan pembiayaan. Akan tetapi untuk nasabah yang tergolong menengah kebawah yang membutuhkan tempat tinggal mendapat kelonggaran nominal uang muka.

Saat ini uang muka bukan menjadi keharusan hanya untuk kategori bangunan tertentu yang mengharuskan uang muka sehingga untuk kalangan menengah kebawah tidak dipersulit. 


\section{Analisis Penerapan Asas Kesetaraan dalam Klausul Tentang Kewajiban-Kewajiban Nasabah}

Akumulasi klausul yang berisi kewajiban-kewajiban nasabah selama perjanjian berlangsung adalah:

a. Membayar harga jual rumah ditambah marjin keuntungan sesuai akad yang disepakati;

b. Memenuhi seluruh persyaratan pembiayaan berdasarkan prinsip murabahah;

c. Wajib membayar denda atas tunggakan sesuai dengan ketentuan bank;

d. Melakukan pembayaran secara angsuran sampai seluruh utang murabahah lunas;

e. Wajib menyerahkan rumah yang dibiayai guna menjamin pembayaran kembali utang murabahah;

f. Wajib memberikan keterangan secara benar atas pertanyaan pihak bank;

g. Wajib memelihara rumah yang dibiayai dengan fasillitas pembiayaan sesuai dengan tujuan pembiayaan;

h. Wajib menyerahkan rumah yang dijaminkan apabila nasabah tidak mampu memenuhi kewajibannya untuk membayar angsuran;

i. Wajib menutup asuransi atas rumah atau barang yang dijaminkan selama jangka waktu pembiayaan;

j. Nasabah wajib membayar seketika dan sekaligus melunasi sisa hutang apabila nasabah tidak mungkin lagi atau diperkirakan tidak akan mampu lagi untuk memenuhi kewajiban.

Berdasarkan hukum islam kewajiban-kewajiban yang dibebankan kepada nasabah pada dasarnya ditentukan oleh para pihak dengan berlandaskan asas kerelaan dan kebebasan sepanjang tidakbertentangan dengan syariah.

Dari paparan di atas yang tidak sesuai dengan asas Taswiyahadalah terkait dengan denda yang ditentukan secara sepihak dan kewajiban pembayaran sekaligus apabila nasabah dalam kesulitan/ kesempitan. Seharusnya pihak bank memberi kelonggaran akan kewajiban tersebut dengan pertimbangan ekonomi nasabah yang jatuh baik karena musibah dan/atau lainnya. Sehingga nasabah mempunyai waktu untuk mengembalikan pembiayaan dari bank dengan catatan kesungguhan nasabah dalam melakukannya.

\section{Analisis Penerapan Asas Kesetaraan dalam Klausul Tentang Penyelesaian Sengketa}

Pada akad disebutkan bahwa jika terjadi perselisihan pada awalnya akan dilakukan musyawarah antara bank dengan nasabah, dan selanjutnya apabila tidak tercapai kesepakatan akan diputus oleh pangadilan agama peraturan administrasi dan prosedur pengadilan agama yang keputusannya mengikat para pihak yang bersengketa.

Apabila dikaji dari kitab fiqh, maka terdapat beberapa patokan yang dapat diambil sebagai cara penyelesaian sengketa dalam bertransaksi, 
yaitu: perdamaian (Shulhu), Arbitrase (Tahkim), dan Proses Peradilan (alQadha).

Hal di atas sesuai dengan ketentuan yang tercantum dalam pasal 55 Undang-undang Nomor 21 tahun 2008 tentang perbankan Syariah yang mengatur mengenai penyelesaian sengketa ekonomi syariah.

Pada klausul penyelesaian sengketa sangat penting untuk kedua belah pihak bersama dana secara seimbang menentukan bentuk pilihan penyelesaian sengketa yang sesuai dengan ketentuan peraturan sehingga dapat terpenuhinya asas Taswiyah(kesetaraan).

\section{PENUTUP}

Konsep kesetaraan menurut hukum perikatan syariah adalah keseimbangan posisi/ kedudukan antara para pihak yang bertransaksi atau terkait kontrak. Keseimbangan/ kesetaraan yang dimaksud adalah antara apa yang diberikan dan apa yang diterima dalam porsi yang sama serta sama pula dalam menangung resiko yang mungkin terjadi dikemudian hari. Dengan terakomodasinya kesetaraan hak dan kewajiban para pihak dalam berkontrak meminimalisir terjadinya prasangka maupun sengketa.

Asas kesetaraan (musawwa) belum secara sempurna diterapkan pada seluruh pasal dalam akad pembiayaan murabahah yang mengandung hak dan kewajiban antara kedua belah pihak. Terdapat 2 (dua) kelompok klausul yang belum mewujudkan asas musawwa dalam pasal-pasalnya yaitu: Pertama, Kelompok klausul tentang jumlah pembiayaan, tujuan pembiayaan, bentuk pembiayaan, dan batas waktu pembiayaan yang didalamnya menyebutkan jumlah pembiayaan yang terdiri dari harga jual ditambah marjin keuntungan. Dalam menentukan besarnya marjin keuntungan dan batas waktu pembiayaan haruslah berdasarkan pada kesepakatan kedua belah pihak bukan hanya pada pihak bank sebagai penyedia pembiayaan. Kedua, Kelompok klausul tentang kewajiban bagi nasabah yang salah satu bunyinya terkait dengan denda atas tunggakan, seharusnya dalam menentukan besaran denda itu tidak boleh dibuat secara sepihak saja, tetapi haruslah berdasarkan dengan kesepakatan antara kedua belah pihak yang melakukan kontrak. Sehingga tidak memberatkan bagi pihak nasabah. 


\section{DAFTAR PUSTAKA}

Ali, M. D. (1990). Hukum Islam: Pengantar ilmu hukum dan tata hukum Islam di Indonesia. Raja Grafindo Persada.

Alwi Hasan, dkk. (2005). Kamus Besar Bahasa Indonesia. Departemen Pendidikan Nasional Balai Pustaka.

Antonio, M. S. (1999). Bank syariah bagi bankir \& praktisi keuangan. Tazkia Institute.

Arwani, A. (2016). Akuntansi Perbankan Syariah: Dari Teori ke Praktik (Adopsi IFRS). Deepublish.

Ascarya. (2007). Akad \& produk bank syariah. Raja Grafindo Persada.

Badrulzaman, M. D. (2001). Kompilasi hukum perikatan: Dalam rangka memperingati memasuki masa purna bakti usia 70 tahun. Citra Aditya Bakti.

Dewi, G. (2008). Aspek-Aspek Hukum Dalam Perbankan \& amp: Perasuransian Syariah Di Indonesia Ed 3. Kencana.

Hardini, I., \& Giharto, M. H. (2007). Kamus perbankan syariah: Dilengkapi penjelasan singkat dan perbandingan dengan bank konvensional. Marja.

Hatta, S. G. M. (1999). Beli sewa sebagai perjanjian tak bernama: Pandangan masyarakat dan sikap Mahkamah Agung. Alumni.

Karim, A. (2007). Bank Islam Analisis Figh dan Keuangan. Raja Grafindo Persada.

Miru, A. (2011). Prinsip-prinsip perlindungan hukum bagi konsumen di Indonesia. Raja Grafindo Persada.

Mughits, A. (2008). Kompilasi Hukum Ekonomi Syari'ah (KHES) dalam Tinjauan Hukum Islam. Al-Mawarid Journal of Islamic Law, 18, 59033.

Muhammad. (2002). Bank Syariah: Analisis Kekuatan, Kelemahan,Peluang, dan Ancaman. Ekonisia.

Mujieb, M. A. (1994). Kamus istilah fiqih. Pustaka Firdaus.

Munawwir, A. W. (1984). Kamus al-Munawwir Arab-Indonesia. P. P. alMunawwir.

Nakha'i, I., \& Ma'sum, Moh. A. (2011). Mengenal Qawa'id Fiqhiyyah. Ibrahimy Press.

Rahman, A. (2007). Inilah Materi Pelatihan PERMA Nomor 3 Tahun 2017Direktorat Jenderal Badan Peradilan Agama. https: / / badilag.mahkamahagung.go.id/seputar-ditjenbadilag/seputar-ditjen-badilag/inilah-materi-pelatihan-perma-nomor3-tahun-2017

Saeed, A. (2004). Menyoal bank syariah: Kritik atas interpretasi bunga bank kaum Neo Revivalis. Paramadina.

Siregar, A. F. (2020). Peraturan Mahkamah Agung Republik Indonesia Nomor 2 Tahun 2008 tentan... [Education]. https: / /www.slideshare.net/AdnanSiregar/peraturan-mahkamahagung-republik-indonesia-nomor-2-tahun-2008-tentang-kompilasihukum-ekonomi-syariah-buku-i-sd-iv 
Wirdyaningsih. (2005). Bank dan Asuransi Islam di Indonesia. Prenada Media.

Wiroso. (2005). Jual beli murabahah. UII Press.

Yasardin. (2018). Asas Kebebasan Berkontrak Syariah. Prenada Media.

Yulianti, R. T. (2008). Asas-Asas Perjanjian (Akad) dalam Hukum Kontrak Syari'ah. Jurnal Fakultas Hukum UII. 